Int. J. Electrochem. Sci., 13 (2018) 10733 - 10750

\title{
Electrochemical and Spectroscopic Studies on the Interaction Modes of Calf Thymus DNA with Antibacterial Schiff Bases obtained from Substituted Salicylaldehydes and Sulfamethizole
}

\author{
Vahide Pehlivan ${ }^{1}$, Ender Biçer ${ }^{1, *}$, Yeliz Genç Bekiroğlü ${ }^{2}$, Necmi Dege $e^{3}$ \\ ${ }^{1}$ Department of Chemistry, Faculty of Arts and Sciences, Ondokuz Mayis University, 55139 Atakum- \\ Samsun, TURKEY \\ ${ }^{2}$ Department of Herbal and Animal Production, Bafra Vocational School, Ondokuz Mayıs University, \\ 55400 Bafra-Samsun, TURKEY \\ ${ }^{3}$ Department of Physics, Faculty of Arts and Sciences, Ondokuz Mayıs University, 55139 Atakum- \\ Samsun, TURKEY \\ *E-mail: ebicer@omu.edu.tr
}

doi: $10.20964 / 2018.11 .40$

Received: 26 June 2018 / Accepted: 3 September 2018 / Published: 1 October 2018

In this study, two Schiff bases have been prepared from the condensation of sulfamethizole (SMTZ) with 3-methoxy and 5-nitro derivatives of salicylaldehyde. These compounds have been characterized by elemental analysis, FT-IR, UV-Vis, ${ }^{1} \mathrm{H}-\mathrm{NMR}$, melting point and X-ray measurements. The in vitro anti-bacterial properties of these Schiff bases against various microorganisms (E. coli ATCC 25922, $S$. aureus ATCC 25923 and trimethoprim sulfamethoxazole resistant clinical isolate E. coli (SXT-R E. coli)) have been also investigated. The Schiff base with $-\mathrm{NO}_{2}$ (Schiff base B, MIC: $0.5 \mu \mathrm{g} \mathrm{mL}{ }^{-1}$ ) shows stronger antibacterial activity than SMTZ, other reactive compounds and the Schiff base with $\mathrm{OCH}_{3}$ (Schiff base A) against $S$. aureus ATCC 25923. The interaction of the Schiff bases with calf thymus DNA (CT-DNA) in the physiological $\mathrm{pH}$ (7.4) was studied by electrochemical and spectroscopic methods. The electrochemical and spectroscopic data revealed that Schiff bases bind to CT-DNA in 1:1 stoichiometry. The binding affinity followed the order Schiff base A > Schiff base B. It has been found that the binding affinity orders determined from different methods are in good agreement with each other. The obtained results indicate that Schiff base A binds to CT-DNA by means of electrostatic forces; however, Schiff base B could interact with CT-DNA molecule by intercalative mode.

Keywords: Antimicrobial activity, DNA interaction, Schiff bases, Substituted salicylaldehydes, Sulfamethizole.

FULL TEXT 
(C) 2018 The Authors. Published by ESG (www.electrochemsci.org). This article is an open access article distributed under the terms and conditions of the Creative Commons Attribution license (http://creativecommons.org/licenses/by/4.0/). 